\title{
Carlo Cafiero and the International in Italy
}

\section{From Marx to Bakunin}

\author{
Mathieu Léonard \\ Translated from the French by Constance Bantman
}

The history of internationalism has been written many times, and has come to focus on a few familiar categories and famous fights. In the case of Italy, the most famous of these fights pitched Marx against Bakunin. Thus, in 19o9, the German-Italian sociologist Roberto Michels claimed that "Bakuninism" had set the scene for Marxism in Italy. This testified to the prevalence of these interpretative frameworks. ${ }^{1}$ A biographical trajectory may prove valuable to avoid repeating these frameworks: history on an individual scale may help us grasp the changing nature of situations and therefore revise some interpretations and open up new paths for further research.

It may be the case that the unusual itinerary of Carlo Cafiero, a major player within the International's Italian Federation - which first split from the General Council even before the Hague congress - epitomises the stakes of the International's history in Italy and the complex tensions between the stances inspired by Marx and Bakunin respectively. Moreover, this provides food for thought regarding the role of irrationality, interpersonal relations and subjectivity in political choices. Indeed, in the fight for influence unfolding in Italy, Bakunin's closeness to a handful of Italian players may have exerted powerful attraction over the small initial group of internationalists - against which the general Council's cold and distant injunctions were bound to remain powerless. The history of the Italian Federation of the International therefore testifies to the singular paths taken by the various tendencies - be they autonomous or not - of the International Working Men's Association (IWMA), which, as it fell apart, failed in pointing out one single organisational way to the sections which it had been instrumental in setting up. Lastly, this founding history of Italian anarchism must be placed in its specific context and be seen as part of a - thwarted - desire for continuity with the fighting spirit of the Risorgimiento generation, and therefore as breaking away from their sacrifices.

In historiographic terms, James Guillaume's archival and memorial work was a precursor in that it sought to retrace the dynamics of anti-authoritarian

1 Storia del marxismo in Italia. Compendio critico. Con annessa bibliografia (Rome, 19o9).

(C) MATHIEU LÉONARD, 2018 | DOI 10.1163/9789004335462_025

This is an open access chapter distributed under the terms of the prevailing CC-BY-NC License. 
internationalists. Cafiero's itinerary can be followed in Guillaume's Memoir on the International ${ }^{2}$ as well in the latter's introduction to a Compendium of Das Kapital in 1910. ${ }^{3}$ The publication of Max Nettlau's Bakunin e l'Internazionale in Italia in $1928,{ }^{4}$ with a preface by Errico Malatesta, was the last work to be both a transcription of direct memory and a historian's work. In the 1850-6os, the historian Pier Carlo Masini ${ }^{5}$ inserted the history of the internationalists and Cafiero - whose biography he wrote - in the legacy of Italian anarchism. Followed by Enzo Santarelli, T.R. Ravindranathan and the American Nunzio Pernincone, ${ }^{6}$ whereas in 2005, in Apostles and agitators, ${ }^{7}$ the historian Richard Drake later regarded Cafiero as part of the Italian Marxist tradition, as its dissident forerunner. Finally, let us note Piero Brunello's ${ }^{8} 2009$ study, with its renewed approach to the history of the International in Italy, breaking away from uniform readings, testifying to the vitality and diversity of the sections existing in Italy, and connecting them with a period of modernisation for the Italian police.

Cafiero's romantic appeal has inspired literary and cinematic creations. He was turned into a novel character in 1927 by Riccardo Baccheli, in Il diavolo al Pontelungo, where his activism was depicted sarcastically. In 1971, Cafiero's figure was also a source of inspiration, as well as a political stake, in the film of the Taviani brothers (who were close to the Communist Party), San Michele aveva un gallo, inspired both by a novel by Tolstoy and the experience of the Matese insurrection, in which Cafiero took part in 1877. The film's character, Giulio Manieri, now pathetic, symbolises the obsolescence of inconsequential romantic revolutionary socialism in the face of the emergent scientific

2 James Guillaume, L'Internationale. Documents et souvenirs (1864-1878) (Paris, 1905-1910).

3 Carlo Cafiero, Abrégé du Capital de Karl Marx (1910).

4 Max Nettlau, Bakunin e l'Internazionale in Italia dal 1864 al 1872 (Edizioni del Risveglio, 1928).

5 Pier Carlo Masini, Gli Internazionalisti e la Banda del Matese, 1876-1878 (Milano [etc.], 1958); La Federazione Italiana dell'Associazone Internazionale dei Lavorati. Atti ufficiali 1871-1880 (atti congressuali; indirizzi, proclami, manifesti) (Milano, 1963); Storia degli anarchici italiani. Da Bakunin a Malatesta (1862-1892) (Milano, 1969); Cafiero, (Milano, 1974).

6 Enzo Santarelli, Il socialismo anarchico in Italia, (Milano, 1959); T.R. Ravindranathan, "Bakunin in Naples: an assessmen", The Journal of Modern History, 53, 2 (June 1981), pp. 189-212; T.R. Ravindranathan, Bakunin and the Italians (McGill, 1988). Nunzio Pernicone, Italian Anarchism, 1864-1892 (2009). The work of the labour movement's biographical archives [hereafter Авмо] in Genoa is also of note. They published Emilio Gianni's L'Internazionale italiana fra libertari ed evoluzionisti. I congress della Federazione Italiana e della Federazione Alta Italia dell'Associazione Internazionale dei lavoratori, 1872-1880 (Pantarei, 2008), http://www .abmo.it.

7 Richard Drake, Apostles and Agitators: Italy's Marxist Revolutionary Tradition (Harvard, 2003).

8 Storie di anarchici et du spie, Polizia e politica nell'Italia liberale, (Roma, 2009). 
socialism, with its political apparatus, in accordance with the left's hegemonic interpretation - although this narrative was disrupted at the time of the film's release by the autonomist movements rejecting the traditional party and trade union structures.

This presentation does not seek to bring any new insights into Cafiero's life, which has been examined in great detail, but its main axes will be outlined. Cafiero's legacy is threefold: (1) he was a major actor in the International's implantation in Italy and the Italian Federation's split from the General Council; (2) he took part in evolving anarchist or anarcho-communist principles characterised by their uncompromising stance towards political strategies, as well as developing insurrectional tactics; (3) lastly, he was the first mediator of the critique of political economy, writing one of the first summaries of the first book of Karl Marx's Capital.

\section{The General Council's Failed Implantation}

Carlo Cafiero (1846-1892) had everything to become the first Italian "Marxist"9 although, in the 1870 , the term was irrelevant and anachronistic in its positive acceptation, and was only used until then by Marx's opponents, pejoratively. During his stay in London between July 1870 and May 1871, Carlo Cafiero gave up the diplomatic career to which his bourgeois origins destined him - he came from a very old family of landowners on the Adriatic coast of Puglia. He discovered, as a result of the industrial revolution, the utter destitution of the proletariat of London's East End. On 16 April 1871, he attended a meeting organised by the IWMA, which brought together more than 30,000 people in Hyde Park in support of the Paris Commune. This event was instrumental in winning him over for good to revolution and socialism. He would not be a diplomat; he would be an internationalist.

In the struggle for hegemony between the followers of Bakunin and the General Council, but also in the fight among the Mazzinian tendencies, Cafiero was perceived to have the potential to become the London agent, as the special correspondent in Italy. Cafiero joined the Naples section of the

9 A few words about uses of the term "Marxism" in the early 1870s: it was used almost exclusively by Marx's "Bakuninist" (a mirroring term) opponents. Thus, in the June 1872 Bulletin de la Fédération jurassienne, the "Marxist dynasty", the "Marxist conspiracy" and the "Marxist law" were denounced. Marx was not very keen on the term 'Marxist', as he wrote to British socialist leader Henry Hyndman in a letter dated 2 July 1881: "Party programs ought to keep free of any apparent dependence upon individual authors or books". 
International - "the city where the labour element is the most resistant, the most rebellious to any idea of progress," as Mazzini wrote in his vitriolic attack against both the Commune and the IWMA, published in his own diary La Roma del Popolo in the same period. ${ }^{10}$

It was on 31 January 1869, in Naples, that the first Italian section of the IWMA appeared, but its origins go back to the group formed around Bakunin, Gambuzzi and Saverio Friscia in 1866, which saw the publication of the paper Libertà e Giustizia from August 1867 to February 1868. In March 1869, the section claimed that it already had 1,200 registered workmen - 3,00o in February 1870, when it was first dissolved by the police.

It was dissolved again on 20 August 1871, through a Royal decree. In December 1871, the Federazione Operaia Napoletena was founded, with Errico Malatesta as its secretary. In this transforming section, there were fiery young intellectuals and students, often of middle-class extraction, such as the lawyer Carmelo Palladino, Errico Malatesta (who soon dropped out of medical school) and Emilio Covelli, a former fellow seminary student of Cafiero. It was on the post-Unification frustration of these young people, faced with downward social mobility and turning their backs on Mazzini's and Garibaldi's ideas, that Bakunin could project his hopes for a revolutionary renaissance: "In Italy, one finds what other countries are missing - an ardent, energetic youth, without status, without hope, career, prospects and which, in spite of its middle-class origins, is neither morally nor intellectually spent like other countries' youths. Today, these young people are embracing revolutionary socialism unreservedly $[\ldots]^{\prime \prime 11}$

Italy's "first anarchism" has often been condescendingly reduced to an attempted peasant revolt which was both industrially backwards and politically rash. The context was far from anecdotal: the Risorgimento's broken promises, both social - agrarian reform - and political - a broader franchise - as well as the Italian peninsula's late industrialisation, the North/South divide as well as substantial work migration are well-known factors. Complete with the political imagination of a new generation, itself pervaded with the experience of the "last men of Risorgimento" (Carlo Pisacane, Garibaldi, Fanelli) as well as the working-class's evolution and the symbolical dimension of the Paris Commune, this provides the keys to understanding the Italian internationalists' options. Bakunin's Alliance's radical programme was therefore likely to feed their revolutionary impatience.

\footnotetext{
$10 \quad$ Article dated 13 July 1871.

11 Michel Dragomanov (ed.), Correspondance de Michel Bakounine, Lettres à Herzen et Ogareff (Perrin, 1896), p. 47.
} 
Cafiero corresponded with Engels until June 1872. Since the September 1871 London conference, Engels occupied a pivotal place within the General Council, hunting down factions as "Marx's bulldog", in the words of his recent biographer Tristram Hunt, ${ }^{12}$ while Marx sought to devote himself exclusively to his theoretical works. Cafiero's letters initially testified to a social situation of extreme deprivation and the "barbarian state" of Southern Italy. He thought that he could discern the signs of the "most dramatic social revolution. ${ }^{13}$ " He also informed him of the latest progress of the International. On 18 October 1871, he wrote: "There is not a single important city where the International does not have at least some foothold [...] The last zone which still belonged to Mazzini's defeated and fully washed-out army, [is being invaded] by the International".

In November, Engels congratulated Cafiero on the text signed by "Some Internationalists", which criticised Mazzini's despotism and antisocialism. It was in fact a memorandum written by Bakunin and entitled "To my Italian friends", on the occasion of the working-class Congress called to Rome by the Mazzinian party on 1st November 1871. Cafiero told Engels the truth: "You should congratulate Bakunin, not me." Above all, Engels endeavoured to get Cafiero to formally fight against Bakunin's champions, whom he characterised as "professional sectarians" aiming for their personal doctrine to prevail within the International.

Cafiero, urged to unmask the Alliance's "henchmen", understood this fixation less and less: "Regarding Bakunin," Cafiero wrote on 12 July 1871, "I can confirm that he has many friends in Naples who share some of his principles and truly have some common views; but to claim that there is a sect, a party dissenting from the principles of the General Council - I completely negate that." Detecting a hint of scepticism in his correspondent's tone, Engels could sense that he was about to change sides: "They are all pro-Bakunin in Naples and only one of them, Cafiero, is at least good-willed. He is the one I correspond with." "Cafiero is a good man," he wrote to Lafargue on 11 March 1872, "a natural mediator, and as such he is naturally weak; if he doesn't pull himself together soon, I will give up on him too."

Following Cafiero, therefore, shows the impact of social and political conditions, but also of human beings and their abilities to organise. Cafiero was one individual among others who was instrumental in giving the Italian situation its specificity. But this was not all.

\footnotetext{
12 Tristram Hunt, The Frock-Hunted Communist: The Revolutionary Life of Friedrich Engels (2009).

13 This quote and the following ones are extracted from Del Bo Giuseppe, La corrispondenza di Marx e Engels con Italiani 1848-1895 (Milano, 1964).
} 


\section{Cafiero in the Intimate Alliance}

The demonisation of Bakunin aroused Cafiero's curiosity and, through Fanelli, in mid-May he left to meet him in Locarno, Switzerland, where he stayed for a month. On 21 May, Bakunin noted in his diary: "All day with Fanelli and Cafiero. Perfectly-completed alliance."14 From then on, agreeing on everything with Bakunin, Cafiero - under the aliases Armando and Gregorio - penetrated the first circle of the close correspondents of the secret Alliance, an international network of a few individuals between Italy, Switzerland, Spain and Russia, whose only mystery, James Guillaume claimed, resided in the "free rapprochement of men, without forms, solemnity, arcane rituals, simply because they trusted one another and perceived getting on as preferable to isolated action." However, entire sections of their clandestine activities are to remain shrouded in mystery since it is known from Marc Vuillemier's work on James Guillaume's archives $^{15}$ in particular that much of their correspondence was destroyed at different points.

On 19 June 1875 Cafiero sent Engels the letter in which he broke away from the General Council - a letter read and approved by Bakunin beforehand: "Your Communist programme is, in my view, in its positive part, a great reactionary absurdity,"16 he wrote in reference to the Communist Manifesto, to which Bakunin had alerted him and which he perceived to be a kind of hidden programme for the General Council. Cafiero reworked an argument made by Bakunin, who saw in Resolution IX, voted at the London Congress, "panGermanic claims" - given that "the proletariat can act as a class only by establishing itself as a distinct political party." This reference to the Manifesto was a sign that the text was becoming known among Bakunin's champions, since he had been involved in its first translation into Russian. ${ }^{17}$ Interestingly, around the same period, Marx and Bakunin seemed to reassess the Manifesto's programmatic points: "The practical application of the principles will depend, as the Manifesto itself states, everywhere and at all times, on the historical

\footnotetext{
14 Guillaume, L'Internationale. Documents et Souvenirs.

15 Marc Vuillemier, « Les archives de James Guillaume », Le Mouvement social, 48 (Jul.-Sept. 1964), pp. 95-108.

16 Jacques Freymond (ed.), La Première Internationale. Recueil de documents, vol. 4, (Geneva, 1971).

17 This rediscovery was far from being available to a large audience at the time. Only in 1882 did Laura Lafargue give a complete translation to the French paper L'Egalité - the 1848 translation had completely disappeared. The first part-translations came even later in Italy, including in 1892 in the paper Lotta di classe.
} 
conditions for the time being existing, and, for that reason, no special stress is laid on the revolutionary measures proposed at the end of Section II. [...] One thing especially was proved by the Commune, viz., that "the working class cannot simply lay hold of the ready-made state machinery, and wield it for its own purposes" they wrote in the preface to the German second edition of the Manifesto in June 1872.

Engels and Cafiero's correspondence was remarkable in that it was probably the only direct exchange between a protagonist belonging to the current often referred to as "antiauthoritarian" and an eminent General Council delegate. While the letter's feverish style and occasionally muddled arguments mean that it will most likely never feature in any anthology of anarchist texts, this document still makes it possible to highlight the key disagreements with the General Council's centralism: (1) the aspiration to turn itself into a form of executive body for the IWMA; (2) the very principle of turning the proletariat into a political party; (3) the systematic castigation of Bakunin; (4) a sense of autonomy heightened by the rejection of the Italian state's political centralism. It was through a saying from Puglia, "the octopus should be cooked in its own water," that Cafiero manifested his profound attachment to the principle of autonomy from the General Council's guidelines, as well as from those of the Italian central state.

Besides, Engels and Marx's attempts to provide an indirect reply to the Italian internationalists' options cast a long shadow, in ideological terms. The publication, in 1873 and 1874, of two texts addressed to the Italian socialists, in an Almanac from Bignami editions ${ }^{18}$ - "On Authority" by Engels and "Political Indifferentism" by Marx - provided cornerstones in the argument against anarchism, subsequently taken up in all Marxist-Leninist vade mecums. Cafiero's U-turn signified the loss of the General Council's most important correspondent in Italy. There only remained one General Council ally - "albeit not a very energetic one," according to Engels -, in Lodi: the moderate socialist printer Enrico Bignami.

The founding Congress of the Italian section of the International, bringing together twenty-one sections, twenty-five delegates, on 4 August, 1872 in Rimini, presided by Cafiero, saw the famous resolution declaring that "the Italian Federation dissolved any solidarity with London's General council." Cafiero stood as the General Council's "resolute opponent" as he accompanied James Guillaume, in late September 1872 , as a mere spectator, to the Hague Congress, 
where he lost patience with Guillaume's ecumenism: "Best to stay alone than make concessions." 19

The second Congress, in Bologna, from 15 to 17 March 1873, brought together sixty sections, from Bologna, Florence, Pisa, Ravenna, Turin, and Sicily. None of the Southern sections was in contact with the General Council, but with Bakunin via Cafiero. However, Cafiero was not just Bakunin's vassal. He even emancipated himself from him in the wake of the events at La Barronata and the aborted Bologna insurrection, during which Cafiero lost all of his inheritance, which he had earmarked to serve the cause. Bakunin himself was excluded from the close circle which he had set up in September 1874. Cafiero had described Mazzini as "a man of the past," and the generational process also seemed to work against Bakunin.

1875 saw the victory of internationalist ideas over Mazzinianism, and a newfound vigour in creating sections. According to the Italian Federation's internal reports, the overall number of sections in the peninsula rose from 129 in February 1874 to 155 in April ${ }^{20}$ - an increase in the number of members from 26,704 to $32,450^{21}$ Internal numbers, such as those of the police, were probably exaggerated, but in a report dated 4 June 1873, Florence's police chief reckoned that "there are many workers and craftsmen who support its principles, but are afraid of joining the International for fear of losing their jobs or because they cannot afford the dues." 22

\section{The Temptation of Illegalism}

Faced with the severe economic crisis of 1873-74, Italy underwent many popular insurrections which led the internationalists to adopt an insurrectional strategy. The most radical republican currents also saw the era as propitious to an overthrow of the monarchy. On 2 August 1874 authorities arrested republican leaders preventatively, during a meeting at villa Ruffi, near Rimini, and dismantled the internationalist sections of Emilia-Romagna. The August 1874

19 Max Nettlau, "Les Origines de l'Internationale antiautoritaire", Le Réveil communisteanarchiste, Geneva, 597, (16 Sept. 1922).

20 The breakdown for the latter figure is 36 in Tuscany, 30 in Emilia-Romagna. 18 in Umbria, Lazio and Marches, 17 in Naples and Southern Italy, 15 in Sicily, 11 in Lombardy, 9 in the Venetian, 8 in Piedmont, 6 in Liguria and 1 in Sardinia. Franco Della Peruta, "La consistenza numerica dell'Internazionale in Italie nel 1874", Movimento Operaio, 3-4, (Dec. 1949-Jan. 1950), pp. 104-106.

Quoted in Nunzio Pernicone, Italian Anarchism, 1864-1892 (1993). 
Bologna insurrection planned by anarchists petered out even before it started; it was meant to bring together 3,00o insurgents, and in fact there were only 200, who were promptly arrested.

In the face of police repression, the Italian Federation underwent two sluggish years, which coincided with the moderate left's rise to power. The third clandestine - Congress of the Italian federation, in late October 1876, set out a tactic based on "propaganda by the deed," relying on riots and insurrection: "The Italian federation believes that the - insurrectional - deed is the most effective means of propaganda and the only one which, without corrupting or deceiving masses, may penetrate into the deepest layers of society and draw the live forces of mankind into the struggle that the International is leading!" It is interesting to examine this terminology of propaganda by the deed, which has been traced back to anarchism only, in the context of continuity with the Risorgimento, but whose filiation should be analysed more closely. The patriot and revolutionary Carlo Pisacane (1818-1857) appears as a forerunner of Italian anarchism, ${ }^{23}$ and he described his faith in the primacy of insurrection over ideas in terms similar to those of the Italian Federation: "Profonda mia convinzione di essere la propaganda dell'idea une chimera e l'istruzione popolare un'assurdità. Le idee nascono dai fatti e non questi da quelle, e il popolo non sarà istrutto, ma sarà ben tosto istrutto quando sarà libero." 24

It was with the rather proactive purpose of triggering the masses' spontaneity that, in early April 1877, 30 internationalists, including Malatesta and Cafiero, attempted to lead an insurrection in the Matese Mountains in Southern Italy. Ill-prepared and without any real local knowledge, the insurgents were easily arrested by the police on 12 April, on the spot where comrades were supposed to join them. "The Mateste Gang," in remand for over a year, were eventually acquitted by a popular jury in August 1878 due to a lack of evidence, especially relating to the accidental death of a policeman.

This aborted guerrilla has of course been used as an argument to castigate the inconsistency of this nascent anarchism, relying on adventurism, vanguardism, fascination with social bandits, conspiracies ... However, while their failure reflects rather poorly on them, the internationalists were acting in a

23 In 1988, an article in a historical anarchist journal founded by Errico Malatesta was entitled: Un precursore des communism anarchico: Carlo Pisacane, by Francesco Lamendola, Umanità Nova, year 68, (26 February 1988).

24 "I am deeply convinced that propaganda by the idea is a chimera and popular instruction an absurdity. Ideas are born from facts, not the opposite, and the people will not be free because they are educated, and they will very soon be educated when they are free." Saggio sulla rivoluzione, a posthumous book published in 1860 . 
context of intense social discontent. Their attempt took place 15 years after the Piedmont's army crushed the brigantaggio postunitario and Carmine Crocco's guerrilla, in those same mountains. Costa, who did not get involved in the attempt, actually tried to provide it with a rational explanation during the 1877 federalist congress in Verviers: "In almost all the Southern Italian provinces, propaganda, as it is understood in Western countries, is near impossible ... The only means which peasants had so far to escape the government's and the landlords' tyranny was very primitive: they would grab a gun, get a few comrades together and became robbers. Generally speaking, robbers are not hated by the people." 25 This undoubtedly was a longing for "widespread robbery" under the unitary banner of the "insurgent masses", against "the rich and the authorities", in keeping with a powerful Bakuninian imagination; above all, however, the insurgents wanted to experiment with exemplary rather than directional tactics.

Nonetheless, observing unbearable inequalities was far certainly not the preserve of revolutionary socialists. Pasquale Villari's Southern Letters, and investigations by Leopoldo Franchetti and Sidney Sonnino raised the alarm regarding both Southern Italy's destitution, where "the worst of the old feudal regime and new agrarian capitalism coexisted", ${ }^{26}$ and the dangers of "socialism", which Villari regarded as "the most dangerous among modern diseases."

The International was outlawed again. At the 8 September 1877 federalist congress in Verviers, Andrea Costa, who had found refuge in Geneva, reported on the atmosphere of widespread hostility towards the internationalists: "The right wing used to treat us like political enemies, and the left has sought to disparage us and to get us to be regarded as plain criminals, lazy individuals, vagrants who, possessing nothing and wanting to do nothing else, attacked other people's lives and property. "The Italian internationals," Nicotera declared [in Parliament], "are not philosophers like the Germans; they are camorrists in Naples, Mafiosi in Sicily, throat-slicers in Romagna."27

A trend towards the dissolution of solidarity spread within the socialist movement, which could not see past the Italian internationalists' illegalism. Jules Guesde called them "the Cerreto fugitives." ${ }^{28}$ Vorwärts, the German

25 Freymond, La Première Internationale. Recueil de documents.

26 Condizioni economiche ed amministrativedelle province napoletane: Abruzzi e MoliseCalabrie e Basilicata. Appunti di viaggio [pubblicato insieme a La mezzeria in Toscana, di Sidney Sonnino], (Firenze, 1875).

27 Freymond, La Première Internationale. Recueil de documents.

28 In the Parisian paper Le Radical; reported by Guillaume in L'Internationale, vol. 3, pp. 561. 
Sozial-Demokratie's main organ, claimed that the insurrection had nothing to do with the International, that the insurgents were "mere criminals" (einfaches Raubgesindel). Benoît Malon poured scorn over the insurgents. "Lastly, in Zurich's Tagwacht, the organ of the Schweizerischer Arbeitbund, Hermann Greulich implied that Cafiero, Malatesta and their companions were "provocateurs," and drew a parallel between the Italian internationalists and the Empire's white shirts", James Guillaume noted in his brief biography of Cafiero. ${ }^{29}$

The ideological positions of the Italian sections thus fluctuated with these power struggles, and also with individual and generational changes, as well as these insurrections and the experience of illegalism in the 1870 s. Lastly Cafiero's trajectory makes it possible to complicate traditional interpretations.

\section{When Cafiero Promoted Marx}

Due to the hostility - at least in political terms - which they experienced, the Internationalists had to evaluate their own experience critically. Jail fulfilled its classic role as a site of political education for Cafiero, who studied Marx's Capital based on the translation by Joseph Roy dated 1875 , sent to him by James Guillaume. Cafiero saw the book as a "remarkable weapon of war", and decided to write a more accessible version for Italian audiences. Besides, despite the argument with Marx, Bakunin's allies were undeniably among the first in socialist circles to perceive the theoretical importance of his work. Il Capitale di Carlo Marx brevemente compendiato da Carlo Cafiero published by Bigami editions in Milan in 1879 - the same legalistic socialist who had published Engels and Marx's texts against anarchism - was in fact a pioneering incursion of Marx's work into Italy, ten years before Antonio Labiola's works.

In his compendium, Cafiero eagerly insisted on the inhumane effects of the industrial capitalist system, through the historical example of the British proletariat's development, but also on what appeared to him as instructive for contemporary Italian opinion, that is to say the process whereby capital accumulation was effected through the violent expropriation of the larger part of the people, peasants and craftsmen. When, in 1879, Marx received at his house two Italian copies of Cafiero's compendium, he had every reason to be surprised by their origin. According to his daughter Laura, this did not prevent Marx from regarding “Cafiero's work as a very good lay account of his surplus

29 These attacks are recalled in his preface to Carlo Cafiero, Abrégé du Capital de Karl Marx, (Stock, 1910). 
value theory." ${ }^{30}$ Cafiero distinguished between Marx's critical economy writings and his so-called political theory. He looked for an anarchist-communist synthesis, founded on the scientific tools of Marxism and libertarian requirements, that is to say antiparliamentarianism and the rejection of the state. His compendium was to follow the vagaries of history. It is well-known that the first edition held pride of place in the book collection of Mussolini's father. There was a second edition, with a preface by the anarchist Luigi Fabbri, in 1913, then a third in 1920. After the downfall of fascism, the book was republished by Marxist-Leninist publishers, obliterating all references to the author's anarchism.

"From 1879 onwards," Enzo Santarelli noted, "the crisis of Italian internationalism coincided with the onset of a - very gradual - progression of political democracy in Italy - with the left's rise to power and the extension of

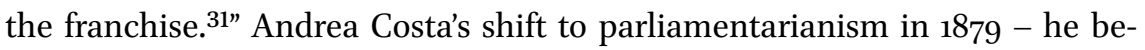
came the first socialist member of the Italian Parliament in 1882 - reinforced Cafiero's irretrievably antiparliamentarian positions and the conundrums facing Italian anarchism, as it was deprived of an organic connection with the nascent labour movement. After 1882, the last period of Cafiero's life saw him in a tragic state of permanent dementia, expressed among other things by a form of mystical exaltation and acute paranoia, until his death in Noceria Inferiore's lunatic asylum, aged forty-five, on 7 June 1892 , following a bout of gastric tuberculosis.

The circulation and reception of ideas have trajectories that are serpentine, but nonetheless logical if the expectations of go-betweens are taken into account. Without reneging in the slightest on his political choices, which cannot be labelled simply as "Bakuninist", Cafiero translated the works of Marx a reminder that translation is also an intellectual adaptation - thereby exposing the many ways of accessing "Marxist" ideas in the early twentieth century.

What can this trajectory - briefly summarised here - tell us about the seeming opposition between Marxism and anarchism supposedly characterising Italy? First, that it is not possible to reduce the history of struggles and the individuals fighting them to their sole ideological basis, however fractious the latter may be. Secondly, that the way in which men who went on to become prominent figures in a movement developed their ideas was through very diverse sources and re-readings, drawing from ideas and alternatives which were both substantial and differentiated. Lastly, that the Italians' anarchist positions

30 James Guillaume, "Carlo Cafiero et Karl Marx, Deux lettres inédites », La Vie ouvrière (5 February 1912).

31 Enzo Santarelli, « L'anarchisme en Italie », Le Mouvement social, 83, (Apr.-Jun. 1973). 
in the years 1870-1900 and their dedication to the cause could certainly lead to new research.

Such complexity also protects us against a linear reading and the notorious "enormous condescension of posterity," whereby this period's revolutionary buoyancy may be seen as a mere proto-socialism, both archaic and accidental, on the part of an Italian labour movement which allegedly then returned naturally to the safe road of political modernity through parliamentary ways. 